\title{
Effect of tropical cyclones on the stratosphere-troposphere exchange observed using satellite observations over the north Indian Ocean
}

\author{
M. Venkat Ratnam ${ }^{1}$, S. Ravindra Babu ${ }^{2}$, S. S. Das ${ }^{3}$, G. Basha ${ }^{1}$, B. V. Krishnamurthy ${ }^{4}$, and B. Venkateswararao ${ }^{2}$ \\ ${ }^{1}$ National Atmospheric Research Laboratory (NARL), Gadanki, India \\ ${ }^{2}$ Centre for Earth, Atmosphere and Weather Modification Technologies (CEA\&WMT), \\ Jawaharlal Nehru Technological University, Hyderabad, India \\ ${ }^{3}$ Space Physics Laboratory (SPL), VSSC, Trivandrum, India \\ ${ }^{4}$ CEBROSS, Chennai, India \\ Correspondence to: M. Venkat Ratnam (vratnam@narl.gov.in)
}

Received: 8 December 2015 - Published in Atmos. Chem. Phys. Discuss.: 18 January 2016

Revised: 23 June 2016 - Accepted: 27 June 2016 - Published: 15 July 2016

\begin{abstract}
Tropical cyclones play an important role in modifying the tropopause structure and dynamics as well as stratosphere-troposphere exchange (STE) processes in the upper troposphere and lower stratosphere (UTLS) region. In the present study, the impact of cyclones that occurred over the north Indian Ocean during 2007-2013 on the STE processes is quantified using satellite observations. Tropopause characteristics during cyclones are obtained from the Global Positioning System (GPS) radio occultation (RO) measurements, and ozone and water vapour concentrations in the UTLS region are obtained from Aura Microwave Limb Sounder (MLS) satellite observations. The effect of cyclones on the tropopause parameters is observed to be more prominent within $500 \mathrm{~km}$ of the centre of the tropical cyclone. In our earlier study, we observed a decrease (increase) in the tropopause altitude (temperature) up to $0.6 \mathrm{~km}(3 \mathrm{~K})$, and the convective outflow level increased up to $2 \mathrm{~km}$. This change leads to a total increase in the tropical tropopause layer (TTL) thickness of $3 \mathrm{~km}$ within $500 \mathrm{~km}$ of the centre of cyclone. Interestingly, an enhancement in the ozone mixing ratio in the upper troposphere is clearly noticed within $500 \mathrm{~km}$ from the cyclone centre, whereas the enhancement in the water vapour in the lower stratosphere is more significant on the south-east side, extending from 500 to $1000 \mathrm{~km}$ away from the cyclone centre. The cross-tropopause mass flux for different intensities of cyclones is estimated and it is found that the mean flux from the stratosphere to the troposphere for cyclonic storms is $0.05 \pm 0.29 \times 10^{-3} \mathrm{~kg} \mathrm{~m}^{-2}$, and for very severe cyclonic storms it is $0.5 \pm 1.07 \times 10^{-3} \mathrm{~kg} \mathrm{~m}^{-2}$. More
\end{abstract}

downward flux is noticed on the north-west and south-west side of the cyclone centre. These results indicate that the cyclones have significant impact in effecting the tropopause structure, ozone and water vapour budget, and consequentially the STE in the UTLS region.

\section{Introduction}

The tropical cyclones with deep convective synoptic-scale systems, persisting for a few days to week, play an important role in the mass exchange between the troposphere and the stratosphere, and vice versa (Merrill, 1988; Emmanuel, 2005). They transport a large amount of water vapour, energy and momentum to the upper troposphere and lower stratosphere (UTLS) region (Ray and Rosenlof, 2007). Cyclones provide favourable conditions for the entry of the watervapour-rich and ozone-poor air from the surface to the lower stratosphere (LS) and dry and ozone-rich air from the LS to the upper troposphere (UT), leading to the stratospheretroposphere exchange (STE) (Romps and Kuang, 2009; Zhan and Wang, 2012; Vogel et al., 2014). These exchanges occur mainly around the tropopause and change the thermal and chemical structure of the UTLS region. The concentration of the water vapour transported from troposphere to stratosphere is controlled by the cold temperatures present at the tropopause, and this is a major factor in the STE (Fueglistaler et al., 2009). As a consequence, the STE events play an important role in controlling the ozone in the UTLS region, 
which will affect the radiation budget of the Earth atmosphere (IPCC, 1996).

Water vapour has major consequences for the radiative balance and heat transport in the atmosphere. Enhanced ozone loss is a secondary effect of increasing water vapour (Rind and Lonergan, 1995; Forster and Shine, 1999; Dvortsov and Solomon, 2001; Forster and Shine, 2002; Myhre et al., 2007; IPCC, 2007). Even very small changes in lower stratospheric water vapour could affect the surface climate (Riese et al., 2012). Soloman et al. (2010) reported the role of stratospheric water vapour in global warming. LS water vapour plays an important role in the distribution of ozone in the lower stratosphere (Shindell, 2001). It is an important contributor for long-term change in the LS temperatures (Maycock et al., 2014).

In general, most of the air enters into the stratosphere over the tropics (Brewer, 1949; Dobson, 1956). As suggested by Newell and Gould-Stewart (1981), the Bay of Bengal (BoB) is one of the most active regions where tropospheric air enters into the stratosphere. It is also one of the active regions for the formation of deep-convection-associated cyclones which contain strong updrafts. Earlier studies have shown a close relationship between cyclones and moistening of the upper troposphere (Wang et al., 1995; Su et al., 2006; Ray and Rosenlof, 2007).

Several studies have been carried out related to water vapour and ozone transport, as well as STE processes around the UTLS region during cyclones. Koteswaram (1967) described the thermal and wind structure of cyclones in the UTLS region, with the major findings of cold core persisting just above $15 \mathrm{~km}$ and the outflow jets very close to the tropopause. Penn (1965) reported enchantment in ozone and warmer air situated above the tropopause over the eye region during Hurricane Ginny. Danielsen (1993) reported on troposphere-stratosphere transport and dehydration in the lower tropical stratosphere during the cyclone period. Baray et al. (1999) studied the STE during Cyclone Marlene and they observed a maximum of ozone change at $300 \mathrm{hPa}$ level. Zou and $\mathrm{Wu}$ (2005) observed the variations of columnar ozone in different stages of hurricane by using satellite measurements. Bellevue et al. (2007) observed an increase in ozone concentration in the upper troposphere during tropical cyclone (TC) events. The significant contribution of cyclones to the hydration of the UT is reported by Ray and Rosenlof (2007), and injection of tropospheric air into the low stratosphere due to overshooting convection by cyclones is reported by Romps and Kuang (2009). Das (2009) and Das et al. (2016b) have studied the stratospheric intrusion into the troposphere during the passage of cyclone by using mesosphere-stratosphere-troposphere (MST) radar observations. Strong enhancement of ozone in the upper troposphere is observed during TCs over the BoB (Fadnavis et al., 2011). The increased ozone levels in the boundary layer as well as the near surface by as much as 20 to $30 \mathrm{ppbv}$ due to strong downward transport of ozone in the tropical convection is also observed (Betts et al., 2002; Sahu and Lal, 2006; Grant et al., 2008). Cairo et al. (2008) reported that the colder temperatures are observed in the tropical tropopause layer (TTL) region during Cyclone Davina and also reported on the impact of the TCs on the UTLS structure and dynamics at a regional scale. A detailed review on the effect of TCs on the UTLS can be found in same report. Recently, Ravindra Babu et al. (2015) reported the effect of cyclones on the tropical tropopause parameters using temperature profiles obtained from Constellation Observing System for Meteorology, Ionosphere and Climate (COSMIC) Global Positioning System radio occultation (GPS-RO) measurements. Many studies have been carried out on the role of extratropical cyclones in STE (for example Reutter et al., 2015 and references therein), though the quantitative estimates of STE provided by these case studies varied considerably. However, the vertical and horizontal variation of ozone and water vapour in the UTLS region and cross-tropopause flux quantification during cyclones over the north Indian Ocean is not well investigated.

In the present study, we investigate the spatial and vertical variations of ozone and water vapour in the UTLS region for all the cyclones which occurred over the north Indian Ocean during 2007 to 2013, by using Aura Microwave Limb Sounder (MLS) satellite observations. The effect of cyclones on the tropopause characteristics is also presented using COSMIC GPS-RO measurements. We also present the cross-tropopause mass flux estimated for each of the cyclones.

\section{Data and methodology}

In the present study, we used Aura MLS water vapour and ozone measurements (version 3.3) provided by the Jet Propulsion Laboratory (JPL). The version 3.3 was released in January 2011 and this updated version has changed in terms of the vertical resolution. The vertical resolution of the water vapour is in the range 2.0 to $3.7 \mathrm{~km}$ from 316 to $0.22 \mathrm{hPa}$, and the along-track horizontal resolution varies from 210 to $360 \mathrm{~km}$ for pressure greater than $4.6 \mathrm{hPa}$. For ozone, vertical resolution is $\sim 2.5 \mathrm{~km}$ and the along-track horizontal resolution varies between 300 and $450 \mathrm{~km}$ (Livesey et al., 2011). The Aura MLS gives around 3500 vertical profiles per day and it crosses the Equator at $\sim 01: 40$ and $\sim 13: 40$ local time. For calculating the cross-tropopause mass flux, we used ERA-Interim winds obtained during cyclone period.

We have taken the cyclone track information data from India Meteorological Department (IMD) observed best track data for tropical cyclones from the years 2007-2013. During this period, around 50 cyclones formed over the north Indian Ocean. Due to the considerable variability of cyclone life cycles, for the present study we selected only 16 cyclones that lasted for more than 4 days. The tracks of all the cyclones used for the present study are shown in Fig. 1. Ta- 


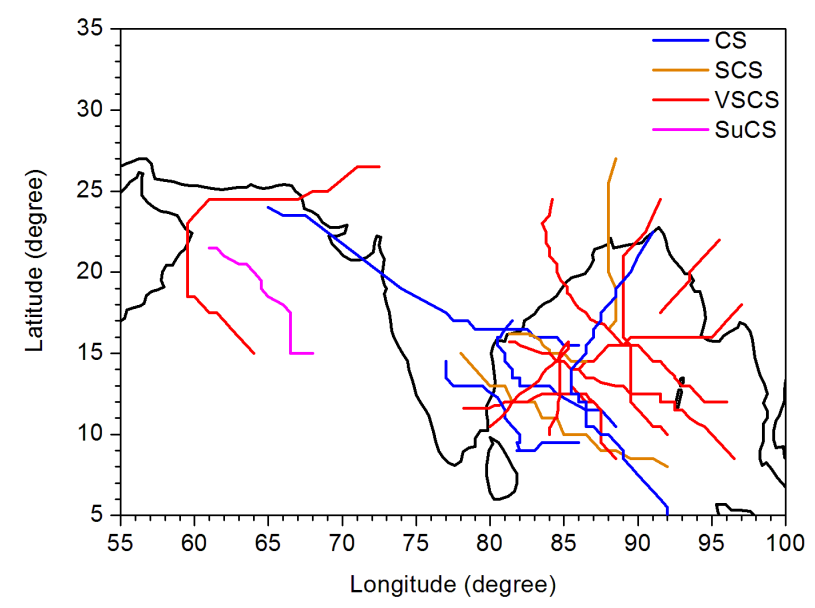

Figure 1. Tropical cyclone tracks of different categories (cyclonic storm (CS, blue colour), severe cyclonic storm (SCS, orange colour), very severe cyclonic storm (VSCS, red colour), and super cyclonic storm (SuCS, magenta colour)) that occurred over the north Indian Ocean during 2007-2013.

ble 1 shows the classification of the cyclones over the north Indian Ocean. The TCs over the north Indian Ocean are classified into different categories by IMD based on their maximum sustained wind speed. They are classified as (1) low pressure when the maximum sustained wind speed at the sea surface is $<17$ knots $\left(32 \mathrm{~km} \mathrm{~h}^{-1}\right)$, (2) depression $(D)$ at 17-27 knots $\left(32-50 \mathrm{~km} \mathrm{~h}^{-1}\right)$, (3) deep depression (DD) at 28-33 knots $\left(51-59 \mathrm{~km} \mathrm{~h}^{-1}\right)$, (4) cyclonic storm (CS) at 3447 knots $\left(60-90 \mathrm{~km} \mathrm{~h}^{-1}\right)$, (5) severe cyclonic storm (SCS) at $48-63$ knots $\left(90-110 \mathrm{~km} \mathrm{~h}^{-1}\right)$, (6) very severe cyclonic storm (VSCS) at 64-119 knots (119-220 $\mathrm{km} \mathrm{h}^{-1}$ ), and (7) super cyclonic storm $(\mathrm{SuCS})$ at $>119$ knots $\left(220 \mathrm{~km} \mathrm{~h}^{-1}\right)$ (Pattnaik and Rama Rao, 2008). Table 2 shows the different cyclones used in the present study and their maximum intensity, sustained time, and sustained time for the peak intensity period of each cyclone. The mean sustained time for cyclones that occurred during pre-monsoon, monsoon, and post-monsoon seasons is $85.5 \pm 52.4,122 \pm 46.5$, and $112.6 \pm 29.47 \mathrm{~h}$, respectively. Out of the 16 cyclones, 4 cyclones (CS-1, SCS-2, and VSCS-1)formed during the pre-monsoon season, $3 \mathrm{cy}-$ clones formed during monsoon season (CS-1, VSCS-1, and SuCS-1) and 9 cyclones (CS-1, SCS-2, and VSCS-6) formed during post-monsoon season (Table 2). Depressions and deep depressions are not considered. The total available MLS profiles for each cyclone that are used in the present study are listed in Table 2. We have $94 \pm 21$ mean MLS profiles for each cyclone used in the present study and when segregated season-wise, there are $108 \pm 6,99 \pm 21$, and $88 \pm 23$ during the monsoon, pre-monsoon, and post-monsoon season, respectively. The available total MLS profiles for each cyclone vary with respect to the sustained period of the cyclone and overall, we have 1517 MLS profiles within $1000 \mathrm{~km}$ from the cyclone centre from all the 16 cyclones (Fig. 2b). Since
Table 1. IMD classification of cyclonic systems over the north Indian Ocean.

\begin{tabular}{lr}
\hline Intensity of the system & $\begin{array}{r}\text { Maximum sustained surface } \\
\text { winds (knots) at sea } \\
\left(1 \mathrm{knot}=0.5144 \mathrm{~m} \mathrm{~s}^{-1}\right)\end{array}$ \\
\hline Low pressure area & $<17$ \\
Depression & $17-27$ \\
Deep depression (DD) & $28-33$ \\
Cyclonic storm (CS) & $34-47$ \\
Severe cyclonic storm (SCS) & $48-63$ \\
Very severe cyclonic storm (VSCS) & $64-119$ \\
Super cyclonic storm (SuCS) & $>119$ \\
\hline
\end{tabular}

there are (temporal) limitations in the satellite measurements, mean cross-tropopause flux is only estimated for those cases of the cyclones that lasted for more than 4 days. However, our quantification of the cross-tropopause flux will not be affected by this limitation as earlier studies revealed that the maximum STE occurs during the mature to peak stage of the cyclone. Details on the selection of 16 cyclones are presented in Ravindra Babu et al. (2015). In Fig. 1, different colours indicate different categories of the cyclones.

\section{Tropopause characteristics observed during cyclones}

As mentioned earlier, in the tropical region, the amount of water vapour transported into the lower stratosphere from the troposphere is controlled by the cold tropical tropopause temperatures (Fueglistaler et al., 2009). Large convection around the eye of the cyclone and strong updrafts near the eye wall transports a large amount of water vapour into the lower stratosphere through the tropopause. In this way, cyclones will affect the tropopause structure (altitude/temperature). Thus, before quantification of STE, we show the tropopause characteristics observed during the TCs. We used postprocessed products of level 2 dry temperature profiles with vertical resolution around $200 \mathrm{~m}$ provided by the COSMIC Data Analysis and Archival Center (CDAAC) for estimating the tropopause parameters during cyclones in the period from 2007 to 2013. COSMIC GPS-RO is a constellation of six microsatellites equipped with GPS receivers (Anthes et al., 2008). We also used CHAllenging Minisatellite Payload (CHAMP) GPS-RO data that are available between the years 2002 and 2006 and COSMIC data from 2007 to 2013 for obtaining background climatology of tropopause parameters over the north Indian Ocean.

The climatological mean of all the tropopause parameters is obtained by combining GPS-RO measurements obtained from CHAMP and COSMIC (2002-2013). The tropopause parameters include cold-point tropopause altitude $(\mathrm{CPH})$ and temperature (CPT), lapse rate tropopause altitude (LRH) and temperature (LRT), and the thickness of the tropical tropopause layer (TTL), defined as the layer between convective outflow level $(\mathrm{COH})$ and $\mathrm{CPH}$, and these parameters 
Table 2. Tropical cyclones which occurred during different seasons, cyclone name, cyclone intensity (CI), cyclone period, total sustained time, sustained time with maximum intensity, and total number of available MLS profiles.

\begin{tabular}{lllrrrr}
\hline Season & Cyclone name & $\begin{array}{l}\text { Cyclone } \\
\text { intensity (CI) }\end{array}$ & $\begin{array}{r}\text { Cyclone } \\
\text { period (days) }\end{array}$ & $\begin{array}{r}\text { Total sustained } \\
\text { time (h) }\end{array}$ & $\begin{array}{r}\text { Sustained time with } \\
\text { maximum intensity (h) }\end{array}$ & $\begin{array}{r}\text { Total available } \\
\text { MLS profiles }\end{array}$ \\
\hline Monsoon & 03B (2007) & CS & $>4$ & 75 & 6 & 104 \\
(JJA) & PHET (2010) & VSCS & $>4$ & 168 & 42 & 116 \\
& Gonu (2007) & SuCS & $>4$ & 123 & 72 & 105 \\
\hline Pre-monsoon & Mahasen (2013) & CS & $>4$ & 24 & 24 & 119 \\
(MAM) & Aila (2009) & SCS & 4 & 72 & 9 & 79 \\
& Laila (2010) & SCS & 4 & 96 & 27 & 82 \\
& Nargis (2008) & VSCS & $>4$ & 150 & 87 & 118 \\
\hline Post-monsoon & Nilam (2012) & CS & $>4$ & 102 & 36 & 52 \\
(SON) & Jal (2010) & SCS & 4 & 99 & 30 & 75 \\
& Helen (2013) & SCS & 4 & 78 & 30 & 72 \\
& Giri (2010) & VSCS & 4 & 66 & 66 & 65 \\
& Phailin (2013) & VSCS & $>4$ & 147 & 36 & 111 \\
& Leher (2013) & VSCS & $>4$ & 114 & 72 & 114 \\
\hline SIDR (2007) & VSCS & $>4$ & 138 & 36 & 104 \\
Winter & Madi (2013) & VSCS & $>4$ & 150 & 36 & 90 \\
\hline (DJF) & Thane (2011) & VSCS & $>4$ & 120 & & \\
\hline
\end{tabular}
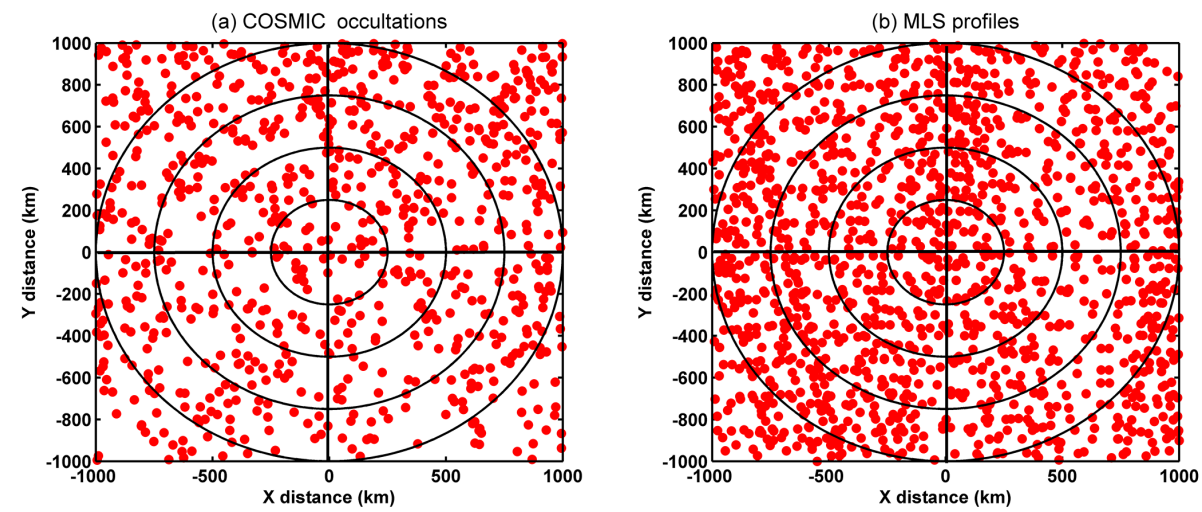

Figure 2. Cyclone-centred composite of total available (a) COSMIC GPS RO occultations and (b) MLS profiles obtained from all the 16 cyclones that are used in the present study.

are calculated for each profile of GPS-RO collected during the above-mentioned period. First, we separated the RO profiles available with respect to distance away from the cyclone centre, around $1000 \mathrm{~km}$ for an individual cyclone for each day of the respective cyclone. After separating, we calculated the tropopause parameters as mentioned above for each RO profile. The total number of occultations used in the present study is shown in Fig. 2a. Then we separated the tropopause parameters with respect to the different cyclone intensity. After estimating the tropopause parameters for all the 16 TCs with respect to different intensity, a cyclonecentre composite of all tropopause parameters is obtained. After careful analysis, it is found that there is not much variation in the tropopause parameters observed between D and DD, and between CS and SCS, and thus they are com- bined to DD and CS, respectively. To quantify the effect of the TCs on the tropopause characteristics, the climatological mean is removed from the individual tropopause parameters. The climatological mean tropopause parameters is estimated from the temperature profiles obtained by using GPSRO data from 2002 to 2013 . We also calculated the difference of tropopause parameters for different cyclone intensities (figures are not shown). Figure 3 shows the cyclonecentred composite of the mean difference in the tropopause parameters $(\mathrm{CPH}, \mathrm{LRH}, \mathrm{CPT}$, LRT, $\mathrm{COH}$, and TTL thickness) between climatological mean (2002-2013) and individual tropopause parameters observed during cyclones (irrespective of cyclone intensity), and more detailed results on the effect of TCs on the tropopause variations and mean temperature structure in UTLS region during TCs can be found 

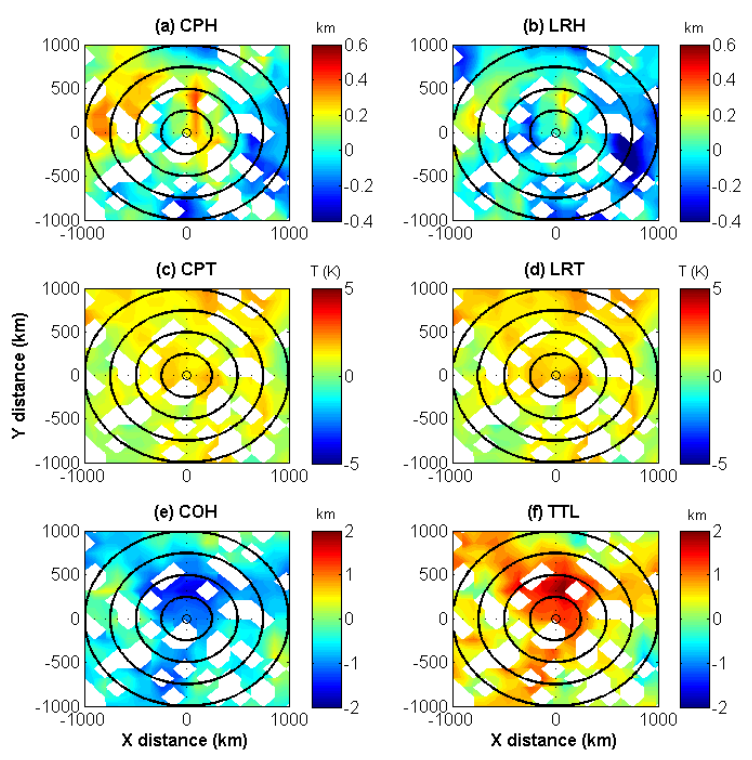

Figure 3. Cyclone-centred composite of mean difference in the tropopause parameters between climatological mean (2002-2013) and individual tropopause parameters observed during cyclones (irrespective of cyclone intensity) in (a) $\mathrm{CPH}(\mathrm{km})$, (b) LRH $(\mathrm{km})$, (c) CPT (K), (d) LRT (K), (e) COH (km), and (f) TTL thickness $(\mathrm{km})$. Black circles are drawn to show distances 250, 500, 750, and $1000 \mathrm{~km}$ away from the cyclone centre.

in Ravindra Babu et al. (2015). We have reported that the $\mathrm{CPH}(\mathrm{LRH})$ is lowered by $0.6 \mathrm{~km}(0.4 \mathrm{~km})$ in most of the areas within a $500 \mathrm{~km}$ radius of the cyclone centre, and the temperature (CPT/LRT) is more or less colder or equal to the climatological values from the area around $1000 \mathrm{~km}$ from the cyclone centre. Note that the effect of a cyclone can be felt up to $2000 \mathrm{~km}$ away but since the latitudinal variation also comes into the picture when we consider a $2000 \mathrm{~km}$ radius, we restrict our discussion related to variability to within $1000 \mathrm{~km}$ of the cyclone centre. COH (TTL thickness) has increased (reduced) up to $2 \mathrm{~km}$ within $500 \mathrm{~km}$ of the cyclones and in some areas up to $1000 \mathrm{~km}$. Note that this decrease in TTL thickness is not only because of pushing up of the $\mathrm{COH}$ but also due to a decrease of $\mathrm{CPH}$. From the above results, we concluded that the tropical tropopause is significantly affected by the cyclones and the effect is more prominent within $500 \mathrm{~km}$ of the cyclone centre. These changes in the tropopause parameters are expected to influence water vapour and ozone transport in the UTLS region during cyclones.

\section{Results and discussion}

\subsection{Ozone variability in the UTLS region during cyclones}

To see the variability and the transport of ozone during the passage of cyclones, we investigate the spatial and vertical variability of ozone in the UTLS region using MLS satellite observations. As mentioned in Sect. 2.1, we also separated the MLS profiles based on the distance from the TC centre for each day of the individual cyclone. From all the $16 \mathrm{cy}-$ clone cases, we separated the available MLS profiles with respect to distance from the cyclone centre, around $1000 \mathrm{~km}$, and we also separated the MLS profiles with respect to different intensities of the cyclones. Figure 4 shows the normalized cyclone-centred composite of mean ozone mixing ratio (OMR) observed during cyclones (irrespective of cyclone intensity) at $82,100,121$, and $146 \mathrm{hPa}$ pressure levels during 2007-2013. Note that we have a reasonable number of MLS profiles (1517) from 16 cyclones to generate the meaningful cyclone-centre composite of ozone. Black circles are drawn to show distances $250,500,750$, and $1000 \mathrm{~km}$ away from the cyclone centre. Since large variability in OMR is noticed from one pressure level to another, we normalized the values to the highest OMR value at a given pressure level. The highest OMR values at 82, 100, 121, and $146 \mathrm{hPa}$ pressure levels are $0.38,0.28,0.19$, and 0.13 ppmv, respectively. Large spatial variations in the OMR are observed with respect to the cyclone centre. At $82 \mathrm{hPa}$, higher OMR $(\sim 0.4 \mathrm{ppmv})$ in the south-west (SW) side up to $1000 \mathrm{~km}$ and comparatively low OMR values $(\sim 0.2 \mathrm{ppmv})$ are noticed in the north of the cyclone centre. At $100 \mathrm{hPa}$, an increase in the OMR $(\sim 0.2 \mathrm{ppmv})$ near the cyclone centre within $500 \mathrm{~km}$ is clearly observed. This enhancement in OMR extends up to $146 \mathrm{hPa}$ and is more prominent slightly to the western and eastern side of the cyclone. In general, the large subsidence located at the top of the cyclone centre is expected to bring lower stratospheric ozone to the upper troposphere. This might be the reason for the enhancement of ozone in the cyclone centre within $500 \mathrm{~km}$. Several earlier studies have reported on the intrusion of the stratospheric air into the troposphere due to the subsidence in the eye region (Penn, 1965; Baray et al., 1999; Das et al., 2009, 2016a). The present results also support this aspect that the detrainment of ozone which reached $146 \mathrm{hPa}$ might be due to strong subsidence. Interestingly, an enhancement in OMR in the south-east (SE) side at $121 \mathrm{hPa}$, but not at either 100 or at $146 \mathrm{hPa}$, can be noticed; this needs to be investigated further. Thus, in general, higher ozone concentrations are observed at the cyclone centre within $500 \mathrm{~km}$ and are slightly aligned to the western side of the cyclone centre.

In order to quantify the impact of cyclones on UTLS ozone more clearly, we have obtained anomalies by subtracting the mean cyclone-centred ozone observed during cyclones from the background climatology of UTLS ozone that is 


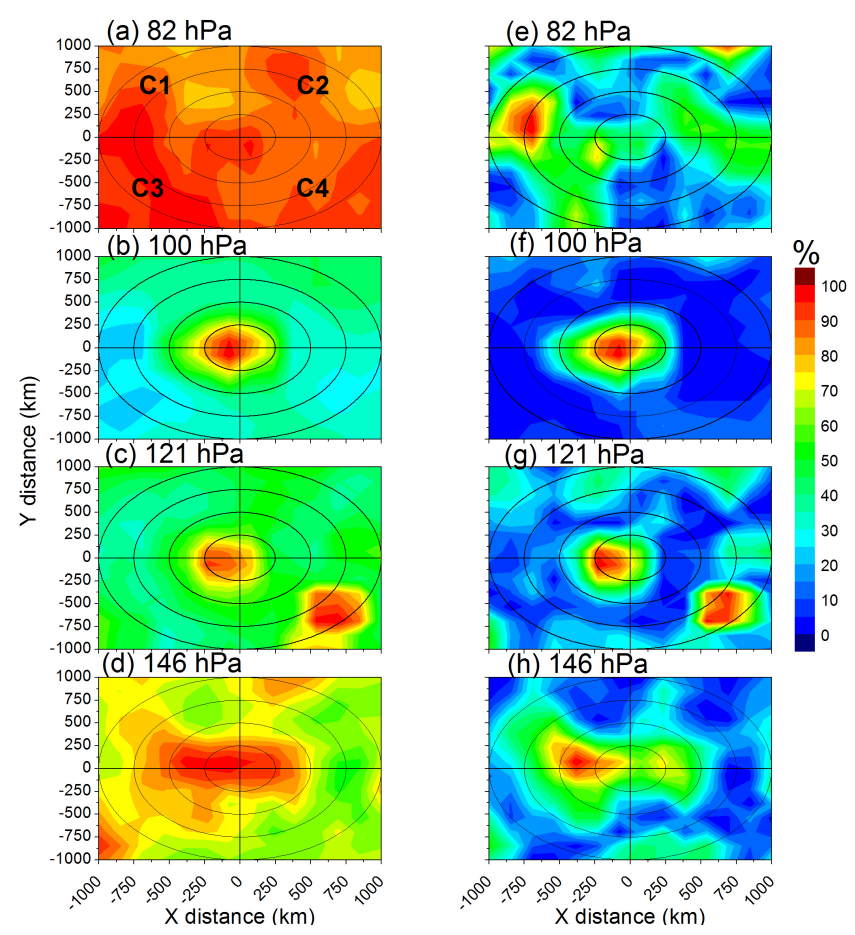

Figure 4. Normalized cyclone-centred composite of mean ozone mixing ratio observed during cyclones (irrespective of cyclone intensity) at (a) 82, (b) 100, (c) 121, and (d) $146 \mathrm{hPa}$ levels by MLS during 2007-2013. (e-h) Same as panels (a-d) but for normalized mean difference in the ozone mixing ratio between climatological mean (2007-2013) and individual events. Black circles are drawn to show distances $250,500,750$, and $1000 \mathrm{~km}$ away from the cyclone centre. Sectors showing C1 (NW), C2 (NE), C3 (SW), and C4 (SE) are also shown in panel (a).

calculated by using the total available MLS profiles from 2007 to 2013. Figure 4e-h show the normalized mean difference of cyclone-centred ozone obtained after removing the background climatology values for different pressure levels shown in Fig. 4a-d. The maximum difference in OMR for corresponding normalized value at $82,100,121$, and $146 \mathrm{hPa}$ pressure levels is $-0.089,-0.19,-0.09$, and $-0.06 \mathrm{ppmv}$, respectively. Enhancement in the OMR $(\sim 0.1 \mathrm{ppmv})$ up to $1000 \mathrm{~km}$ from the cyclone centre is observed at $82 \mathrm{hPa}$. Interestingly, at $100 \mathrm{hPa}$, the OMR is more or less uniform throughout the radius $1000 \mathrm{~km}$ of the cyclone centre except $\sim 500 \mathrm{~km}$ radius from the centre where significant increase of OMR $(\sim 0.2 \mathrm{ppmv})$ is observed. This increase in the OMR is within $500 \mathrm{~km}$ of the cyclone centre and it extends up to $121 \mathrm{hPa}$. However, enhancement in OMR at $146 \mathrm{hPa}$ extends up to $1000 \mathrm{~km}$ but is distributed towards eastern and western sides of the cyclone centre. Thus, it is clear that the detrainment of lower stratospheric ozone will reach up to $146 \mathrm{hPa}$ during the cyclone period due to the presence of strong subsidence in the cyclone centre. We also calculated the cyclonecentre composite of ozone based on different cyclone intensities such as DD, SCS, and VSCS. After carefully going through them, we have found that this detrainment of ozone reaching up to $146 \mathrm{hPa}$ is more in the higher intensity period of the TCs. We do not know what happens below this pressure level due to limitation in the present data; however, studies (Das et al., 2016a; Jiang et al., 2015) have shown that LS ozone can reach as low as the boundary layer during cyclones. It will be interesting to see the variability in the water vapour, as a large amount of it is expected to cross the tropopause during the cyclone period and reach the lower stratosphere.

\subsection{Water vapour variability in the UTLS region during cyclones}

As mentioned earlier, an enormous amount of water vapour is expected to be pumped from the lower troposphere to the upper troposphere, and it can even penetrate into the lower stratosphere during cyclones. To see the linkage between tropopause variability and the transport of water vapour during cyclones, we investigated the horizontal and vertical variability of water vapour in the UTLS region using MLS satellite observations. Figure 5 shows the normalized cyclonecentred composite of mean water vapour mixing ratio observed during cyclones (irrespective of cyclone intensity) at $82,100,121$, and $146 \mathrm{hPa}$ pressure levels observed by MLS during 2007-2013. Black circles are drawn to show distances $250,500,750$, and $1000 \mathrm{~km}$ away from the cyclone centre. The highest water vapour mixing ratio (WVMR) values for corresponding normalized values at $82,100,121$, and $146 \mathrm{hPa}$ pressure levels are 4.44, 4.49, 6.9, and $16.03 \mathrm{ppmv}$, respectively. Significantly higher WVMR values are noticed, extending from 500 up to $1000 \mathrm{~km}$ from the cyclone centre at $121(\sim 6.5 \mathrm{ppmv})$ and $146 \mathrm{hPa}(\sim 15 \mathrm{ppmv})$ levels, with more prominence on the eastern side of the cyclone centre. Comparatively low values are noticed in the centre of the cyclone, especially at $121 \mathrm{hPa}$. These results compare well with higher WVMR observed on the eastern side of cyclones over Atlantic and Pacific oceans (Ray and Rosenlof, 2007). These results also compare well with those reported by Ravindra Babu et al. (2015), who used GPS-RO measured relative humidity $(\mathrm{RH})$ and found enhancement in $\mathrm{RH}$ on the eastern side of the centre in the upper troposphere $(10-15 \mathrm{~km})$ over the north Indian Ocean. Higher WVMR values observed on the eastern side of the cyclone centre might be due to the upper level anticyclonic circulation over the cyclones. It is interesting to note that high WVMR lies not at the centre but extends from 500 to $1000 \mathrm{~km}$ away from the centre of the cyclone. The WVMR is higher at 121 and $146 \mathrm{hPa}$ than at 100 and $82 \mathrm{hPa}$. It seems less water vapour has been transported to 100 and $82 \mathrm{hPa}$ from below. As we know, water vapour mostly originates from the lower troposphere and decreases with height. Therefore, vertical transport of water vapour from the lower troposphere to the UTLS may lead to water vapour enhanced at 121 and $146 \mathrm{hPa}$, and at some time, it reaches higher altitudes. The higher WVMR presented at 

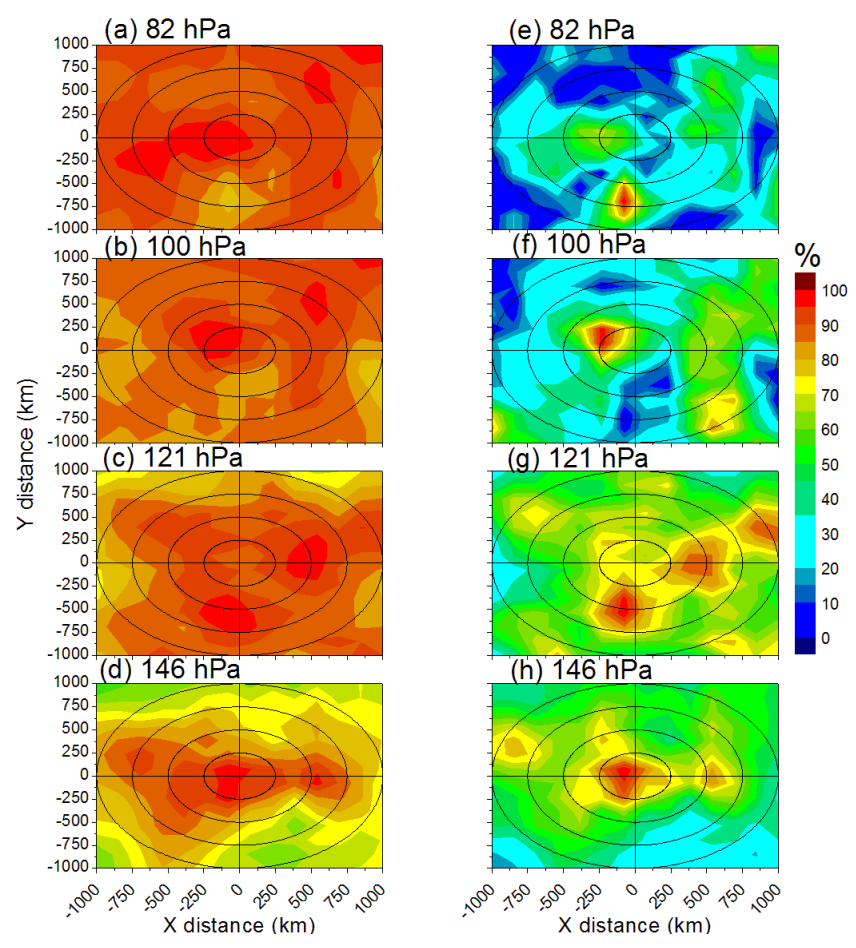

Figure 5. Same as Fig. 4, but for water vapour mixing ratio.

100 and $82 \mathrm{hPa}$ levels shows the signature of the tropospheric air even entering into the lower stratosphere during cyclones.

In order to quantify the impact of cyclones on the UTLS water vapour more clearly, we have obtained anomalies by subtracting the mean cyclone-centred water vapour observed during cyclones from the background climatology mean of UTLS water vapour. Figure 5e-h show the normalized mean difference of the cyclone-centred WVMR obtained after removing the background climatology values for different pressure levels shown in Fig. 5a-d. The maximum difference in WVMR for corresponding normalized values at 82, 100, 121 , and $146 \mathrm{hPa}$ pressure levels is $-0.44,-0.81,-2.55$ and -9.09 ppmv, respectively. More than 7 ppmv differences are observed at $146 \mathrm{hPa}$ within $1000 \mathrm{~km}$ of the centre, and at $121 \mathrm{hPa}$, a difference of $\sim 2 \mathrm{ppmv}$ is noticed, extending up to $2000 \mathrm{~km}$ (figure not shown) on the eastern side of the centre. At 100 and $82 \mathrm{hPa}$ levels, the increase in the WVMR is $\sim 0.8$ and $\sim 0.6 \mathrm{ppmv}$, respectively, and the enhancement is more observed in the north-east (NE) side of the cyclone centre. Thus, a clear STE is evident during the cyclone over the north Indian Ocean where a clear enhancement in the water vapour (ozone) in the lower stratosphere (upper troposphere) is observed. For quantifying the amount of STE, we calculated the cross-tropopause mass flux for each cyclone by considering the spatial extent within $500 \mathrm{~km}$ of the cyclone centre, and results are presented in Sect. 3.3.

\subsection{Cross tropopause flux observed during cyclones}

We adopted the method given by Wei (1987) to estimate the cross-tropopause mass flux, $F . F$ is defined as

$$
\begin{aligned}
F & =\frac{1}{g}\left(-\omega+V_{\mathrm{h}} \times \nabla P_{\mathrm{tp}}+\frac{\partial P_{\mathrm{tp}}}{\partial t}\right) \\
& =\left(-\frac{\omega}{g}+\frac{1}{g} V_{\mathrm{h}} \times \nabla P_{\mathrm{tp}}\right)+\frac{1}{g} \frac{\partial P_{\mathrm{tp}}}{\partial t}=F_{\mathrm{AM}}+F_{\mathrm{TM}},
\end{aligned}
$$

where $\omega$ is the vertical pressure-velocity, $\boldsymbol{V}_{\mathrm{h}}$ is the horizontal vector wind, $P_{\mathrm{tp}}$ is the pressure at the tropopause, $g$ is the acceleration due to gravity, $F_{\mathrm{AM}}$ is the air mass exchange due to horizontal and vertical air motions, and $F_{\mathrm{TM}}$ is the air mass exchange due to tropopause motion.

The wind information is taken from ERA-Interim, and the tropopause temperature and pressure within $500 \mathrm{~km}$ of the cyclone centre is estimated from COSMIC GPS-RO measurements (Ravindra Babu et al., 2015). These values are considered for the maximum intensity day for each of the 16 cyclones and the respective cross-tropopause flux is estimated. Since the above-mentioned results showed that the higher OMR values are observed in the west and north-west (NW) side and more water vapour is located on the eastern side of the cyclone centre, we separated the area into four sectors with respect to the cyclone centre as $\mathrm{C} 1$ (NW side), C2 (NE side), C3 (SW side), and C4 (SE side), respectively, as shown in Fig. 4a. List of cyclones used in the present study with their names, cyclone intensity (CI), centre latitude, centre longitude, and minimum estimated central pressure on their peak intensity day are provided in Table 3. The total flux $F$ (Eq. 1) depends on the air mass exchange due to horizontal and vertical air motion $\left(F_{\mathrm{AM}}\right)$, and the air mass exchange due to tropopause motion itself $\left(F_{\mathrm{TM}}\right)$. Since the number of COSMIC GPS-RO measurements is not sufficient to estimate the second term $\left(F_{\mathrm{TM}}\right)$ for each event, we only calculated the first part of the equation $\left(F_{\mathrm{AM}}\right)$ individually for each of cyclone with respect to the different sectors mentioned above, and the values are presented in Table 3. However, we roughly estimated the contribution of the second term by assuming change in the tropopause pressure by $0.5 \mathrm{hPa}$ increase (decrease) within $6 \mathrm{~h}$. We could see that the cross-tropopause flux for CS is $0.25 \pm 0.07 \times 10^{-3} \mathrm{~kg} \mathrm{~m}^{-2} \mathrm{~s}^{-1}(-0.36 \pm 0.07 \times$ $10^{-3} \mathrm{~kg} \mathrm{~m}^{-2} \mathrm{~s}^{-1}$ ), and for VSCS it is $-0.24 \pm 0.3 \times$ $10^{-3} \mathrm{~kg} \mathrm{~m}^{-2} \mathrm{~s}^{-1}\left(-0.85 \pm 0.3 \times 10^{-3} \mathrm{~kg} \mathrm{~m}^{-2} \mathrm{~s}^{-1}\right)$. If there is a change in the tropopause pressure by a $1 \mathrm{hPa}$ increase (decrease), the flux for CS is $0.55 \pm 0.07 \times$ $10^{-3} \mathrm{~kg} \mathrm{~m}^{-2} \mathrm{~s}^{-1}\left(-0.66 \pm 0.07 \times 10^{-3} \mathrm{~kg} \mathrm{~m}^{-2} \mathrm{~s}^{-1}\right)$, and for VSCS it is $0.06 \pm 0.3 \times 10^{-3} \mathrm{~kg} \mathrm{~m}^{-2} \mathrm{~s}^{-1}(-1.16 \pm 0.3 \times$ $10^{-3} \mathrm{~kg} \mathrm{~m}^{-2} \mathrm{~s}^{-1}$ ).

Figure 6 shows the cross-tropopause flux estimated in each sector from the centre of the cyclone for the different cyclone intensities (estimated based on the cyclone centre pressure). Red lines show the best fit. It clearly shows that the downward flux is always more in $\mathrm{C} 1$ and $\mathrm{C} 3$ sectors, whereas the 
Table 3. Cyclone name, cyclone intensity (CI), centre latitude, centre longitude, estimated central pressure, and estimated cross-tropopause mass flux, with respect to cyclone centre for C1 (NW side), C2 (NE side), C3 (SW side), and C4 (SE side), respectively.

\begin{tabular}{llrrlrrrr}
\hline & & & & & \multicolumn{3}{c}{ Flux at 500 km } \\
\cline { 4 - 9 } Cyclone & CI & $\begin{array}{r}\text { Centre } \\
\text { latitude }\end{array}$ & $\begin{array}{r}\text { Centre } \\
\text { longitude }\end{array}$ & $\begin{array}{l}\text { Estimated central } \\
\text { pressure (hPa) }\end{array}$ & C1 & C2 & C3 & C4 \\
\hline 03B & CS & 23.5 & 66 & $986(25$ Jun 2007) & -0.013 & 0.661 & -0.603 & -0.258 \\
Aila & SCS & 22 & 88 & $968(25$ May 2009) & $1.90 \times 10^{-4}$ & 0.191 & -0.299 & -0.072 \\
Helen & SCS & 16.1 & 82.7 & $990(21$ Nov 2013) & 0.025 & 0.216 & -0.095 & -0.11 \\
Jal & SCS & 11 & 84 & $988(6$ Nov 2010) & 0.025 & 0.384 & -0.4 & -0.218 \\
Laila & SCS & 14.5 & 81 & $986(19$ May 2010) & -0.012 & 0.123 & -0.352 & -0.299 \\
Mahasen & CS & 18.5 & 88.5 & $990(15$ May 2013) & -0.006 & 0.354 & -0.473 & -0.256 \\
Nilam & CS & 11.5 & 81 & $990(31$ Oct 2012) & 0.016 & 0.313 & -0.274 & -0.097 \\
Nargis & VSCS & 16 & 94 & $962(2$ May 2008) & -0.828 & 0.094 & -1.946 & 0.384 \\
Giri & VSCS & 19.8 & 93.5 & $950(22$ Oct 2010) & -0.518 & 0.022 & -0.823 & 0.032 \\
Gonu & SuCS & 20 & 64 & $920(4$ Jun 2007) & -0.502 & 0.123 & -2.563 & 0.37 \\
Lehar & VSCS & 13.2 & 87.5 & $980(26$ Nov 2013) & -0.55 & 0.119 & -2.019 & 0.411 \\
Madi & VSCS & 13.4 & 84.7 & $986(10$ Dec 2013) & -0.375 & 0.054 & -1.449 & 0.352 \\
Phailin & VSCS & 18.1 & 85.7 & $940(11$ Oct 2013) & -0.9 & 0.179 & -2.576 & 0.479 \\
Phet & VSCS & 18 & 60.5 & $964(2$ Jun 2010) & -1.058 & 0.203 & -2.698 & 0.559 \\
SIDR & VSCS & 19.5 & 89 & $944(15$ Nov 2007) & -0.493 & 0.066 & -0.926 & 0.231 \\
Thane & VSCS & 11.8 & 80.6 & $970(29$ Dec 2011) & -1.272 & 0.356 & -2.979 & 0.558 \\
\hline
\end{tabular}

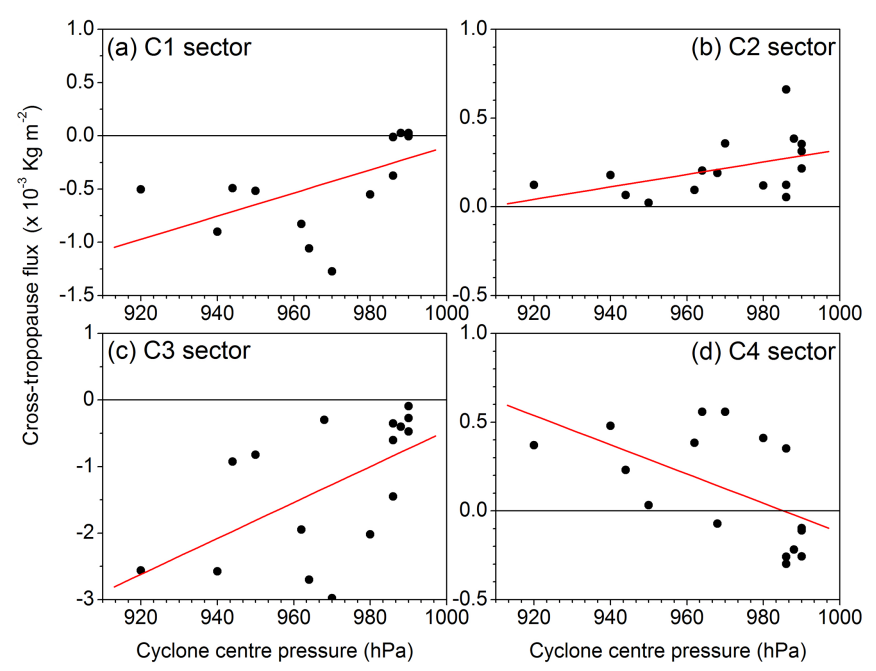

Figure 6. Cross-tropopause flux estimated in the (a) $\mathrm{C} 1$ (NW), (b) $\mathrm{C} 2$ (NE), (c) $\mathrm{C} 3$ (SW), and (d) C4 (SE) sectors from the centre of cyclone for different cyclone intensities (estimated based on cyclone centre pressure). Red lines show the best fit.

C2 sector shows a more upward flux. The flux itself varies with cyclone intensity, and it is found that there is an increase in the downward flux as the cyclone centre pressure decreases, particularly for $\mathrm{C} 1$ and $\mathrm{C} 3$ sectors, whereas in the $\mathrm{C} 4$ sector, an increase in the upward flux is seen as the cyclone intensity increases, but the flux is always upward (positive) in the $\mathrm{C} 2$ sector, irrespective of the cyclone intensity. The second term (in Eq. 1) itself corresponds to the air mass exchange from the tropopause motion, and generally during the cyclone period there is an $\sim 400 \mathrm{~m}$ difference in tropopause altitude (LRH) within $500 \mathrm{~km}$ of the centre of the cyclone (Fig. 3). Thus, the spatial and temporal variation of the tropopause during the cyclones itself is very important to decide whether the flux is downward or upward. Interestingly, $\mathrm{C} 1$ and $\mathrm{C} 3$ sectors of the cyclone show dominant downward mean flux and $\mathrm{C} 2$ and $\mathrm{C} 4$ sectors show dominant upward mean flux with values of $0.4 \pm 0.4 \times 10^{-3}, 1.2 \pm 1.0 \times 10^{-3}$, $0.2 \pm 0.1 \times 10^{-3}$, and $0.12 \pm 0.3 \times 10^{-3} \mathrm{~kg} \mathrm{~m}^{-2}$, respectively. These results strongly support our findings of higher ozone in the NW and SW sides and higher water vapour in the NE side of the cyclone centre. The mean flux is observed to vary with the intensity of the cyclone. Mean flux for the severe cyclonic storms (CS) is $-0.05 \pm 0.29 \times 10^{-3} \mathrm{~kg} \mathrm{~m}^{-2}$, whereas for very severe cyclonic storms (VSCS), it is $-0.5 \pm 1.07 \times$ $10^{-3} \mathrm{~kg} \mathrm{~m}^{-2}$. Reutter et al. (2015) reported that the upward and downward mass fluxes across the tropopause are more dominant in deeper cyclones compared to less intense cyclones over the North Atlantic. Our results are comparable with their results, with the averaged mass flux of the stratosphere to the troposphere as $0.3 \times 10^{-3} \mathrm{~kg} \mathrm{~m}^{-2} \mathrm{~s}^{-1}$ $\left(340 \mathrm{~kg} \mathrm{~km}^{-2} \mathrm{~s}^{-1}\right)$ in the vicinity of cyclones over the North Atlantic Ocean. They also reported that more transport across the tropopause occurred on the west side of the cyclone centre during intensifying and mature stages of the cyclones over the North Atlantic region. 


\section{Summary and conclusions}

In this study, we have investigated the vertical and spatial variability of ozone and water vapour in the UTLS region during the passage of cyclones which occurred between 2007 and 2013 over the north Indian Ocean, by using Aura MLS satellite observations. In order to make a quantitative estimate of the impact of cyclones on the ozone and water vapour budget in the UTLS region, we removed the mean cyclonecentre ozone and water vapour from the climatological mean calculated using MLS data from 2007 to 2013. We estimated the mean cross-tropopause flux for each of the cyclones on their peak intensity day. The main findings are summarized below.

1. A lowering of the CPH $(0.6 \mathrm{~km})$ and $\mathrm{LRH}(0.4 \mathrm{~km}) \mathrm{val}-$ ues with the coldest CPT and LRT $(2-3 \mathrm{~K})$ within a $500 \mathrm{~km}$ radius of the cyclone centre is noticed. A higher $(2 \mathrm{~km}) \mathrm{COH}$ leading to the lowering of TTL thickness $(\sim 3 \mathrm{~km})$ is clearly observed (Ravindra Babu et al., 2015).

2. The impact of cyclones on ozone and the tropopause (altitude/temperature) is more prominent within $500 \mathrm{~km}$ of the cyclone centre, whereas it is high from 500 to $1000 \mathrm{~km}$ in the case of water vapour.

3. Detrainment of ozone is highest in the cyclone centre (within $500 \mathrm{~km}$ of the centre) due to strong subsidence above the cyclone centre, and this detrained ozone reaches as low as the $146 \mathrm{hPa}$ level $(\sim 13-14 \mathrm{~km})$.

4. The detrainment of ozone is higher in the higher intensity period (SCS or VSCS) of the cyclone compared to the low-intensity period (D or DD).

5. Interestingly, significant enhancement in the lower stratospheric $(82 \mathrm{hPa})$ water vapour is noticed in the east and SE side of the cyclone centre.

6. Dominant downward (upward) cross-tropopause flux is observed in $\mathrm{C} 1(\mathrm{NW})$ and $\mathrm{C} 3(\mathrm{SW})(\mathrm{C} 2(\mathrm{NE})$ and $\mathrm{C} 4$ (SE)) sectors of the cyclone.

Figure 7 shows the typical structure (not to scale) of the TC along with convective towers, updrafts, downdrafts, and the above-mentioned tropopause variability, with respect to the cyclone centre, in the form of a schematic diagram. This figure is redrawn from the basic idea given in chap. 9 and Fig. 6 of www.geology.sdsu.edu. The results presented in Figs. 4 and 5 are a composite picture of all 16 cyclones. Because each individual cyclone is different, this composite picture will differ somewhat from the typical structure shown in Fig. 7. The tropopause altitude (CPH) is lowered by $0.6 \mathrm{~km}$ within $500 \mathrm{~km}$ of the centre of the cyclone. The convective outflow level $(\mathrm{COH})$ slightly pushes up $(\sim 2 \mathrm{~km})$ within $500 \mathrm{~km}$ of the centre of the cyclone, but not exactly in

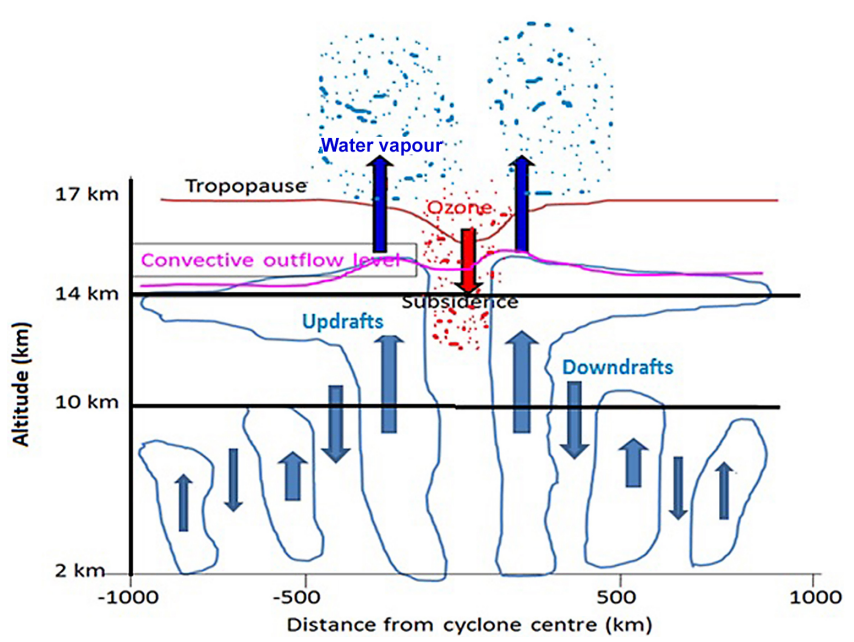

Figure 7. Schematic diagram showing the variability of $\mathrm{CPH}$ (brown colour line) and $\mathrm{COH}$ (magenta colour line) with respect to the centre of cyclone. Spiral bands of convective towers reaching as high as $\mathrm{COH}$ are shown with blue colour lines. Light blue (red) colour up (down) side arrow shows the up drafts (downdrafts/subsidence). Thickness of the arrows indicates the intensity.

the centre. Thus, a decrease of about $3 \mathrm{~km}$ in the TTL thickness is observed within the $500 \mathrm{~km}$ of the cyclone centre. Cyclones include an eye region that extends from a few kilometres to tens of kilometres. Strong convective towers with strong updrafts extending up to the tropopause in the form of spiral bands extending from 500 to $1000 \mathrm{~km}$ are present. Strong water vapour transport into the lower stratosphere $(82 \mathrm{hPa}$ ) while pushing up the $\mathrm{COH}$ is observed around these spiral bands in the present study. Between these spiral bands, an equal amount of subsidence is expected, with strong subsidence existing at the centre of the cyclone. Significant detrainment of ozone present above or advected from the surroundings is observed, reaching as low as $146 \mathrm{hPa}$ at the cyclone centre. Thus, it is clear that ozone reaches the upper troposphere from the lower stratosphere through the centre of the cyclone, whereas water vapour transport into the lower stratosphere will happen within 500 to $1000 \mathrm{~km}$ of the cyclone centre. Since more intense cyclones are expected to occur in a changing climate (Knutson et al., 2010), the amount of water vapour and ozone reaching the lower stratosphere and upper troposphere, respectively, is expected to increase, thus affecting complete tropospheric weather and climate. Future studies should focus on these trends.

\section{Data availability}

We would like to thank COSMIC Data Analysis and Archive Centre (CDAAC) for providing GPS-RO data used in the present study through their FTP site (http:// cdaac-www.cosmic.ucar.edu/cdaac/products.html). The provision of tropical cyclone best track data used in the 
present study by IMD through their website (http://www. rsmcnewdelhi.imd.gov.in) and Aura MLS observations obtained from the GES DISC through their FTP site (https: $/ / \mathrm{mls}$.jpl.nasa.gov/index-eos-mls.php) is highly acknowledged.

Acknowledgements. This work is supported by the Indian Space Research Organization (ISRO) through CAWSES India Phase-II Theme 3 programme. The authors would like to thank the editor, Rolf Müller, and three anonymous reviewers whose comments helped considerably in improving the quality of this paper.

Edited by: R. Müller

Reviewed by: three anonymous referees

\section{References}

Anthes, R. A., Bernhardt, P. A., Chen, Y., Cucurull, L., Dymond, K. F., Ector, D., Healy, S. B., Ho, S.-H., Hunt, D. C., Kuo, Y.-H., Liu, H., Manning, K., McCormick, C., Meehan, T. K., Randel, W. J., Rocken, C., Schreiner, W. S., Sokolovskiy, S. V., Syndergaard, S., Thompson, D. C., Trenberth, K. E., Wee, T.-K., Yen, N. L., and Zeng, Z.: The COSMIC/Formosat/3 mission: Early results, B. Am. Meteorol. Soc., 89, 313-333, 2008.

Baray, J. L., Ancellet, G., Radriambelo T., and Baldy, S.: Tropical cyclone Marlene and stratosphere-troposphere exchange, J. Geophys. Res., 104, 13953-13970, doi:10.1029/1999JD900028, 1999.

Bellevue, J., Baray, J. L., Baldy, S., Ancellet, G., Diab, R. D., and Ravetta, F.: Simulations of stratospheric to tropospheric transport during the tropical cyclone Marlene event, Atmos. Environ., 41, 6510-6526, doi:10.1016/j.atmosenv.2007.04.040, 2007.

Betts, A. K., Gatti, L. V., Cordova, A. M., Silva Dias, M. A. F., and Fuentes, J. D.: Transport of ozone to the surface by convective downdrafts at night, J. Geophys. Res., 107, 8046, doi:10.1029/2000JD000158, 2002.

Brewer, A. W.: Evidence for a world circulation provided by the measurements of helium and water vapor distribution in the stratosphere, Q. J. Roy. Meteor. Soc., 75, 351-363, doi:10.1002/qj.49707532603, 1949.

Cairo, F., Buontempo, C., MacKenzie, A. R., Schiller, C., Volk, C. M., Adriani, A., Mitev, V., Matthey, R., Di Donfrancesco, G., Oulanovsky, A., Ravegnani, F., Yushkov, V., Snels, M., Cagnazzo, C., and Stefanutti, L.: Morphology of the tropopause layer and lower stratosphere above a tropical cyclone: a case study on cyclone Davina (1999), Atmos. Chem. Phys., 8, 34113426, doi:10.5194/acp-8-3411-2008, 2008.

Danielsen, E. F.: In situ evidence of rapid, vertical, irreversible transport of lower tropospheric air into the lower tropical stratosphere by convective cloud turrets and by larger-scale upwelling in tropical cyclones, J. Geophys. Res., 98, 8665-8681, doi:10.1029/92JD02954, 1993.

Das, S. S.: A new perspective on MST radar observations of stratospheric intrusions into troposphere associated with tropical cyclone, Geophys. Res. Lett., 36, L15821, doi:10.1029/2009GL039184, 2009.
Das, S. S., Ratnam, M. V., Uma, K. N., Subrahmanyam, K. V., Girach, I. A., Patra, A. K., Aneesh, S., Suneeth, K. V., Kumar, K. K., Kesarkar, A. P., Sijikumar, S., and Ramkumar, G.: Influence of tropical cyclones on tropospheric ozone: possible implications, Atmos. Chem. Phys., 16, 4837-4847, doi:10.5194/acp16-4837-2016, 2016 a.

Das, S. S., Ratnam, M. V., Uma, K. N., Patra, A. K., Subrahmanyam, K. V., Girach, I. A., Suneeth, K. V., Kumar, K. K., and Ramkumar, G.: Stratospheric intrusion into the troposphere during the tropical cyclone Nilam (2012), Q. J. Roy. Meteor. Soc., doi:10.1002/qj.2810, 2016b.

Dobson, G. M. B.: Origin and Distribution of the Polyatomic Molecules in the Atmosphere, Proc. R. Soc. Lon. Ser. A, 236, 187-193, doi:10.1098/rspa.1956.0127, 1956.

Dvortsov, V. L. and Solomon, S.: Response of the stratospheric temperatures and ozone to past and future increases in stratospheric humidity, J. Geophys. Res., 106, 7505-7514, 2001.

Emanuel, K. A.: Increasing destructiveness of tropical cyclones over the past 30 years, Nature, 436, 686-688, doi:10.1038/nature03906, 2005.

Fadnavis, S., Berg, G., Buchunde, P., Ghude, S. D., and Krishnamurti, T. N.: Vertical transport of ozone and CO during super cyclones in the Bay of Bengal as detected by Tropospheric Emission Spectrometer, Environ. Sci. Pollut. R., 18, 301-315, doi:10.1007/s11356-010-0374-3, 2011.

Forster, P. M. de F. and Shine, K. P.: Stratospheric water vapour changes as a possible contributor to observed stratospheric cooling, Geophys. Res. Lett., 26, 3309-3312, 1999.

Forster, P. M. de F. and Shine, K. P.: Assessing the climate impacts of trends in stratospheric water vapour, Geophys. Res. Lett., 29, 1086-1089, doi:10.1029/2001GL013909, 2002.

Fueglistaler, S., Dessler, A. E., Dunkerton, T. J., Fu, I., Folkins, Q., and Mote, P. W.: Tropical tropopause layer, Rev. Geophys., 47, RG1004, doi:10.1029/2008RG000267, 2009.

Grant, D. D., Fuentes, J. D., DeLonge, M. S., Chan, S., Joseph, E., Kucera, P., Ndiaye, S. A., and Gaye, A. T.: Ozone transport by mesoscale convective storms in western Senegal, Atmos. Environ., 42, 7104-7114, doi:10.1016/j.atmosenv.2008.05.044, 2008.

IPCC: IPCC, Climate Change 1995 - The Science of Climate Change, Contribution of Working Group I to the Second Assessment Report, section 2, edited by: Houghton, J. T., MeiraFilho, L. G., Callander, B. A., Harris, N., Kattenberg, A., and Maskell, K., University Press, Cambridge, UK, 572 pp., 1996.

IPCC: Climate Change 2007: The Physical Science Basis. Contribution of Working Group I to the Fourth Assessment Report of the Intergovernmental Panel on Climate Change, edited by: Solomon, S., Qin, D., Manning, M., Chen, Z., Marquis, M., Tignor, K. B. M., and Miller, H. L., Cambridge University Press, Cambridge, UK and New York, NY, USA, 996 pp., 2007.

Jiang, Y. C., Zhao, T. L., Liu, J., Xu, X. D., Tan, C. H., Cheng, X. H., Bi, X. Y., Gan, J. B., You, J. F., and Zhao, S. Z.: Why does surface ozone peak before a typhoon landing in southeast China?, Atmos. Chem. Phys., 15, 13331-13338, doi:10.5194/acp-1513331-2015, 2015.

Knutson, T. R., McBride, J. L., Chan, J., Emanuel, K., Holland, G., Landsea, C., Held, I., Kossin, J. P., Srivastava, A. K., and Sugi, M.: Tropical cyclones and climate change, Nat. Geosci., 3, 157163, 2010. 
Koteswaram, P.: On the structure of hurricanes in the upper troposphere and lower stratosphere, Mon. Weather Rev., 95, 541-564, 1967.

Livesey, N., Read, W. G., Frovideaux, L., Lambert, A., Manney, G. L., Pumphrey, H. C., Santee, M. L., Schwartz, M. J., Wang, S., Cofield, R. E., Cuddy, D. T., Fuller, R. A., Jarnot, R. F., Jiang, J. H., Knosp, B. W., Stek, P. C., Wagner, P. A., and Wu, D. L.: Earth Observing System (EOS) Aura Microwave Limb Sounder (MLS) Version 3.3 Level 2 data quality and description document, JPL D-33509, JPL publication, New Orleans, USA, 2011.

Maycock, A. C., Joshi, M. M., Shine, K. P., Davis, S. M., and Rosenlof, K. H.: The potential impact of changes in lower stratospheric water vapour on stratospheric temperatures over the past 30 years, Q. J. Roy. Meteor. Soc., 140, 2176-2185, doi:10.1002/qj.2287, 2014.

Merrill, R. T.: Characteristics of the upper-tropospheric environmental flow around hurricanes, J. Atmos. Sci., 45, 1665-1677, doi:10.1175/1520-0469(1988)045<1665:COTUTE >2.0.CO;2, 1988.

Myhre, G., Nilsen, J. S., Gulstad, L., Shine, K. P., Rognerud, B., and Isaksen, I. S. A.: Radiative forcing due to stratospheric water vapour from CH4 oxidation, Geophys. Res. Lett., 34, L01807, doi:10.1029/2006g1027472, 2007.

Newell, R. E. and Gould-Stewart, S.: A stratospheric fountain, J. Atmos. Sci., 38, 2789-2796, doi:10.1175/15200469(1981)038<2789:ASF>2.0.CO;2, 1981.

Pattnaik, D. R. and Rama Rao, Y. V.: Track Prediction of very sever cyclone "Nargis" using high resolution weather research forecasting (WRF) model, J. Earth Syst. Sci., 118, 309-329, 2008.

Penn, S.: Ozone and temperature structure in a Hurricane, J. Appl. Meteorol., 4, 212-216, 1965.

Ravindra Babu, S., Venkat Ratnam, M., Basha, G., Krishnamurthy, B. V., and Venkateswararao, B.: Effect of tropical cyclones on the tropical tropopause parameters observed using COSMIC GPS RO data, Atmos. Chem. Phys., 15, 10239-10249, doi:10.5194/acp-15-10239-2015, 2015.

Ray, E. A. and Rosenlof, K. H.: Hydration of the upper troposphere by tropical cyclones, J. Geophys. Res., 112, D12311, doi:10.1029/2006JD008009, 2007.

Reutter, P., Škerlak, B., Sprenger, M., and Wernli, H.: Stratospheretroposphere exchange (STE) in the vicinity of North Atlantic cyclones, Atmos. Chem. Phys., 15, 10939-10953, doi:10.5194/acp15-10939-2015, 2015.

Riese, M., Ploeger, F., Rap, A., Vogel, B., Konopka, P., Dameris, M., and Forster, P.: Impact of uncertainties in atmospheric mixing on simulated UTLS composition and related radiative effects, J. Geophys. Res., 117, D16305, doi:10.1029/2012JD017751, 2012.
Rind, D. and Lonergan, P.: Modeled impacts of stratospheric ozone and water vapor perturbations with implications for highspeed civil transport aircraft, J. Geophys. Res., 100, 7381-7396, doi:10.1029/95JD00196, 1995.

Romps, D. M. and Kuang, Z. M.: Overshooting convection in tropical cyclones, Geophys. Res. Lett., 36, L09804, doi:10.1029/2009GL037396, 2009.

Sahu, L. K. and Lal, S.: Changes in surface ozone levels due to convective downdrafts over the Bay of Bengal, Geophys. Res. Lett., 33, L10807, doi:10.1029/2006GL025994, 2006.

Shindell, D. T.: Climate and ozone response to increased stratospheric water vapor, Geophys. Res. Lett., 28, 1551-1554, 2001.

Solomon, S., Rosenlof, K. H., Portmann, R. W., Daniel, J. S., Davis, S. M., Sanford, T. J., and Plattner, G.-K.: Contributions of Stratospheric Water Vapor to Decadal Changes in the Rate of Global Warming, Science, 327, 1219-1223, 2010.

Su, H., Read, W. G., Jiang, J. H., Waters, J. W., Wu, D. L., and Fetzer, E. J.: Enhanced positive water vapor feedback associated with tropical deep convection: New evidence from Aura MLS, Geophys. Res. Lett., 33, L05709, doi:10.1029/2005GL025505, 2006.

Vogel, B., Günther, G., Müller, R., Grooß, J.-U., Hoor, P., Krämer, M., Müller, S., Zahn, A., and Riese, M.: Fast transport from Southeast Asia boundary layer sources to northern Europe: rapid uplift in typhoons and eastward eddy shedding of the Asian monsoon anticyclone, Atmos. Chem. Phys., 14, 12745-12762, doi:10.5194/acp-14-12745-2014, 2014.

Wang, C., Crutzen, P. J., Ramanathan, V., and Williams, S. F.: The role of a deep convective storm over the tropical Pacific Ocean in the redistribution of atmospheric chemical species, J. Geophys Res., 100, 11509-11516, doi:10.1029/95JD01173, 1995.

Wei, M. Y.: A new formulation of the exchange of mass and trace constituents between the stratosphere and troposphere, J. Atmos. Sci., 44, 3079-3086, doi:10.1175/1520 0469(1987)044<3079:ANFOTE>2.0.CO;2, 1987.

Zhan, R. and Wang, Y.: Contribution of tropical cyclones to stratosphere-troposphere exchange over the northwest Pacific: estimation based on AIRS satellite retrievals and ERA-Interim data, J. Geophys. Res., 117, D12112, doi:10.1029/2012JD017494, 2012.

Zou, X., and Y. Wu.: On the relationship between Total Ozone Mapping Spectrometer (TOMS) ozone and hurricanes, J. Geophys. Res., 110, D06109, doi:10.1029/2004JD005019, 2005. 